\title{
The small GTP-binding protein Rho is expressed differentially during spore germination of Phycomyces blakesleeanus
}

\author{
Natividad Ramírez-Ramírez, Jesús García-Soto, \\ Angélica González-Hernández and Guadalupe Martínez-Cadena
}

\author{
Author for correspondence: Guadalupe Martínez-Cadena. Tel: +52473243 02. Fax: +5247324302 . \\ e-mail:margua@quijote.ugto.mx
}

Instituto de Investigación en Biología Experimental, Facultad de Química, Universidad de Guanajuato, Apartado Postal 187, Guanajuato, Gto, 36000 Mexico

\begin{abstract}
Evidence has been obtained for the presence of the small 22 kDa GTP-binding Rho protein in dormant spores of Phycomyces blakes/eeanus. Immunoblotting with a polyclonal antibody against $R$ hoA revealed a soluble and membraneassociated 22 kDa protein. When [32P]ADP-ribosylated by Clostridium botulinum $\mathrm{C} 3$ exotoxin the protein had a pl of 5.7, a value similar to that reported for other RhoA proteins. The 22 kDa protein was expressed at all stages of growth investigated, but radiolabelling of the [32P]ADP-ribosylated protein increased when tube-formation occurred and decreased as the hyphae branched. Localization of RhoA during spore germination studied by immunofluorescence microscopy revealed the presence of RhoA in the cell membrane of the spore. When the spore started to swell, RhoA was observed as patches in the cell membrane which become concentrated in the neck region of the site of the protuberation tube, but this protein was never observed at the point of growth of the hyphal tip. The above results suggest that RhoA associated with one or more membrane proteins could participate in the molecular mechanism involved in maintaining cell integrity during the extrusion of the germ-tube of $P$. blakesleeanus.
\end{abstract}

Keywords: GTP-binding proteins, Rho proteins, spore germination, Phycomyces blakesleeanus

\section{INTRODUCTION}

The activation of cell surface receptors leads to a multiplicity of responses, such as growth and morphogenesis, which are accompanied by changes in organization of the cytoskeleton. Cytoskeletal changes after cell activation have been attributed to changes in $\mathrm{pH}, \mathrm{Ca}^{2+}$ or phosphorylation and also to the activation of small GTP-binding proteins of the Rho subfamily (Ridley \& Hall, 1994). The Rho-subfamily proteins modulate signal transduction from plasma membrane receptors and trigger cellular responses related to polarity, motility, cell shape, and rearrangements of the actin cytoskeleton (reviewed by Machensky \& Hall, 1996). Members of the Rho-subfamily, like other GTPbinding proteins, exhibit both GDP/GTP binding and GTPase activities (Nobes \& Hall, 1994). They have GDP-bound inactive and GTP-bound active forms, which are interconvertible by GDP/GTP exchange and GTPase reactions mediated by different proteins (Nobes \& Hall, 1994).
RhoA, RhoB and RhoC isoforms are unique among the many small GTP-binding proteins, including other members of the Rho-subfamily, in that they can be selectively ADP-ribosylated by the C3 exotoxin from Clostridium botulinum; Asn41 is the putative target domain of human Rho protein (Sekine et al., 1989). The ADP-ribosylation of Rho inhibits several cell functions related to the actin-based cytoskeleton and thereby participates in the control of cell shape of higher organisms (Takai et al., 1995).

Saccharomyces cerevisiae grows by budding for cell division. This polarized cell growth is initiated by signals from the cell surface that result in the realignment of the cytoskeleton and the biosynthetic machinery toward a targeting patch at the bud site. Cortical actin patches are localized at the site of bud emergence on unbudded cells, and in small and medium-sized buds in budding cells. Different small GTP-binding proteins have been associated with the bud emergence site of Sacch. cerevisiae (see reviews by Cid et al., 1995; Cabib et al., 
1998). Of these, Rho1p has been localized at the periphery of the bud emergence sites, the staining sites overlapping with those of the cortical patches of actin, even though there is no evidence that the GTP-binding protein is connected with the regulation of the actin cytoskeleton (Yamochi et al., 1994). On the other hand, it has been reported that Rho1p activates glucan synthase, and therefore is required for cell wall synthesis (Drgonová et al., 1996). In Schizosaccharomyces pombe, it has been reported that Rho1p partially complements a geranylgeranyl transferase mutant in which cell wall synthesis is defective, particularly in the glucan synthase activity (Arellano et al., 1996). These results, together with those from Sacch. cerevisiae, suggest that Rho plays a central role in yeast morphogenesis.

Phycomyces blakesleeanus is a zygomycete fungus whose spores need an activation treatment $\left(50^{\circ} \mathrm{C}\right.$ for $3 \mathrm{~min}$, or monocarboxylic acids) in order to induce germination and growth in a suitable culture medium. The germination process involves a morphological transition from an elliptical spore to a spherical cell, and following protrusion of the germ-tube, its elongation and branching (Van Laere et al., 1987). In these stages of development, a dynamic reorganization of the actin cytoskeleton must take place, which may involve the Rho proteins. In the work described here we have demonstrated the presence of RhoA in dormant spores of $P$. blakesleeanus, and investigated its expression and cellular localization during the spore germination process.

\section{METHODS}

Chemicals and reagents. $\left[{ }^{32} \mathrm{P}\right] \mathrm{NAD}\left(1 \cdot 11 \times 10^{14} \mathrm{~Bq} \mathrm{mmol}^{-1}\right)$ was purchased from Amersham. Nucleotides, NAD, Nonidet P40 and antipain were from Sigma. Materials for SDS-PAGE were from Bio-Rad. C3 exotoxin from C. botulinum was purchased from Upstate Biotechnology. Mouse monoclonal and rabbit polyclonal antibodies against RhoA were obtained from Santa Cruz Biotechnology. Other reagents were of the highest quality commercially available.

Strains. The wild-type strain NRRL $1555(-)$ of $P$. blakesleeanus from Northern Regional Research Labs, Peoria, IL, USA, a gift from Dr E. Cerda-Olmedo, was used throughout this work.

Media and cultivation conditions. P. blakesleeanus was maintained and propagated in YPG medium (Bartnicki-Garcia \& Nickerson, 1962). Sporangiospores were produced on YPG solidified with $2 \%(\mathrm{w} / \mathrm{v})$ agar from cultures incubated at $24^{\circ} \mathrm{C}$ for $6 \mathrm{~d}$ under diffused light. To promote germination and growth, the spores were activated chemically by including ammonium acetate to a final concentration of $30 \mathrm{mM}$ in YPG liquid medium and incubated as described by MartínezCadena et al. (1995).

Preparation of cell-free extracts. Cell-free extracts were obtained from spores or mycelia as described by DevezeAlvarez et al. (1996). The crude extracts were centrifuged at $100000 \mathrm{~g}\left(r_{\mathrm{av}}\right)$ for $60 \mathrm{~min}$, and the supernatant (tosol) and mixed-membrane fractions were divided into aliquots and kept at $-20^{\circ} \mathrm{C}$ until use.

Assay of ADP-ribosylation. ADP-ribosylation was carried out in a reaction mixture $(40 \mu \mathrm{l})$ composed of $50 \mathrm{mM}$ Tris $/ \mathrm{HCl}$
$\mathrm{pH} 7 \cdot 4,2 \mathrm{mM} \mathrm{MgCl}, 1 \mathrm{mM}$ ATP, $0 \cdot 2 \%$ (v/v) Nonidet P40, $1 \mathrm{mM}$ EDTA, $1 \mathrm{mM}$ DTT, $2 \mu \mathrm{M}$ NAD, $7 \cdot 4 \times 10^{4} \mathrm{~Bq}\left[{ }^{32} \mathrm{P}\right] \mathrm{NAD}$ $\left(\sim 1 \cdot 11 \times 10^{14} \mathrm{~Bq} \mathrm{mmol}^{-1}\right), 75-100 \mu \mathrm{g}$ protein and, when indicated, $0 \cdot 1 \mu \mathrm{g}$ C. botulinum C3 exotoxin. The reaction proceeded for $30 \mathrm{~min}$ at $37^{\circ} \mathrm{C}$ and was terminated by the addition of $2 \times$ solubilization buffer $[0.25 \mathrm{M}$ Tris $/ \mathrm{HCl} \mathrm{pH} 6 \cdot 8,10 \%$ (v/v) $\beta$-mercaptoethanol, $20 \%$ (v/v) glycerol, $4 \%$ (w/v) SDS, $0.001 \%(\mathrm{w} / \mathrm{v})$ bromophenol blue]. Samples were boiled for $3 \mathrm{~min}$ and subjected to $12 \%$ (v/v) SDS-PAGE (Laemmli, 1970). After electrophoresis the gels were stained with Coomassie blue, dried, and exposed $(7-10 \mathrm{~d})$ to X-OMAT films for autoradiography.

ATPase assay. $\mathrm{H}^{+}$-ATPase was determined by measuring the phosphate released from ATP by the method of Ames (1966) in $0.12 \mathrm{ml}$ of $30 \mathrm{mM}$ Tris/MES pH 6.5, $5 \mathrm{mM} \mathrm{MgSO}_{4}, 3 \mathrm{mM}$ ATP, $1 \mu \mathrm{M}$ valinomycin. Different aliquots of the sucrose gradient containing $75-150 \mu$ g protein were added to start the reaction. This was stopped with $1.88 \mathrm{ml}$ of the molybdate reagent used to measure the released phosphate. The $A_{820}$ was measured after $1 \mathrm{~h}$. Vanadate-sensitive ATPase activity was measured in the presence and absence of $100 \mu \mathrm{M}$ sodium vanadate.

Protein determination. Protein concentration was estimated by the Lowry method using bovine serum albumin as standard.

Western blot analysis. After electrophoresis, proteins were transferred onto nitrocellulose and assayed for immunoreactivity as described by Towbin et al. (1979). Polyclonal antibodies against RhoA were tested at a dilution of $1: 2000$. Sheep anti-rabbit IgG conjugated with horseradish peroxidase was used as secondary antibody and immunoreactivity revealed by chemiluminescence (ECL, Amersham).

Fluorescence microscopy. Cells from different stages of growth were fixed with $4 \%(\mathrm{v} / \mathrm{v})$ formaldehyde in PBS $\mathrm{pH} 7 \cdot 0$ for $24 \mathrm{~h}$. After permeabilization for $5 \mathrm{~min}$ with cold ethanol/ chloroform $(3: 1, v / v)$, fixed cells were incubated for $2 \mathrm{~h}$ with the primary antibody mouse anti-RhoA followed by the addition of donkey anti-mouse-IgG conjugated with fluorescein isothiocyanate. Cells were analysed by epifluorescence microscopy using a Zeiss Axioscop microscope coupled with a no. 9 filter (excitation $450-490 \mathrm{~nm}$, emission $510 \mathrm{~nm})$.

\section{RESULTS}

\section{C3-exotoxin-catalysed ADP-ribosylation of spore membrane and soluble fractions}

Cytosol and mixed-membrane fractions from dormant spores of $P$. blakesleeanus were incubated under ADPribosylation conditions with $\mathrm{C} 3$ exotoxin and $\left[{ }^{32} \mathrm{P}\right] \mathrm{NAD}$. After electrophoretic separation and subsequent autoradiography, a single $\left[{ }^{32} \mathrm{P}\right] \mathrm{ADP}$-ribosylated band with a molecular mass of $22 \mathrm{kDa}$ was observed in both fractions (Fig. 1a, lanes 3 and 4, respectively). When these fractions were incubated with $\left.{ }^{32} \mathrm{P}\right] \mathrm{NAD}$, but without $\mathrm{C} 3$ exotoxin, no $\left[{ }^{32} \mathrm{P}\right] \mathrm{ADP}$-ribosylated protein was observed in the cytosol or in the mixedmembrane fraction (Fig. 1a, lanes 1 and 2, respectively). No auto-ADP-ribosylation of the C3 exotoxin was observed when the toxin was incubated in the presence of $\left.{ }^{32} \mathrm{P}\right] \mathrm{NAD}$ and in the absence of the fungal protein (Fig. 1a, lane 5). Also, we incubated the soluble (Fig. 1b) or the mixed-membrane fraction (Fig. 1c) with increasing concentrations of non-radioactive NAD. The 
(a)

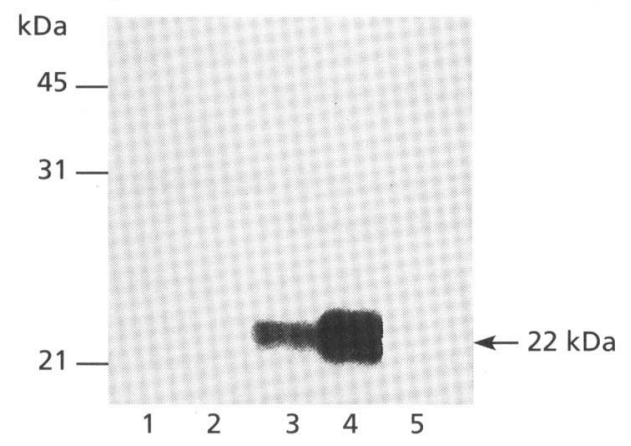

(b)

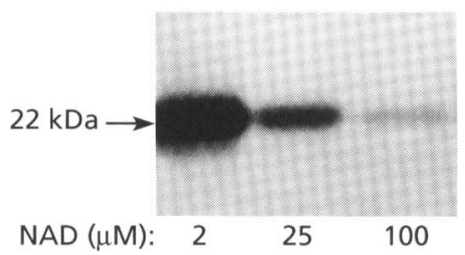

(c)

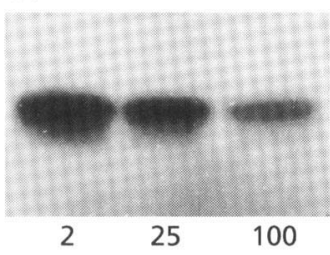

Fig. 1. ADP-ribosylation of a $22 \mathrm{kDa}$ protein by $\mathrm{C} 3$ exotoxin in $P$. blakesleeanus. (a) $100 \mu \mathrm{g}$ cytosol (lanes 1 and 3) or mixedmembrane fraction (lanes 2 and 4) from spores of $P$. blakesleeanus was incubated under conditions for ADPribosylation in the absence (lanes 1 and 2) or in the presence (lanes 3 and 4) of C. botulinum C3 exotoxin. As control, C3 exotoxin was incubated without the cellular extracts (lane 5). Samples were then subjected to PAGE and autoradiography. (b, c) The soluble (b) and mixed-membrane (c) fractions were incubated under ADP-ribosylation conditions in the presence of C3 exotoxin and 2, 25 or $100 \mu \mathrm{M}$ non-radioactive NAD. Identical results were obtained in another five experiments.

intensity of the $22 \mathrm{kDa}\left[{ }^{32} \mathrm{P}\right] \mathrm{ADP}$-ribosylated protein decreased with the increase of non-radioactive NAD. The above results with $\mathrm{C} 3$ exotoxin demonstrate the presence of Rho protein(s) in both cytosol and mixedmembrane fractions of the fungal spores.

\section{Subcellular distribution of the Rho protein}

Since both the cytosol and the mixed-membrane fraction from spores contained the Rho protein, we studied the distribution of this protein in different membrane fractions. We separated the spore homogenate on an isopycnic sucrose gradient (Fig. 2a) and looked for the C3 exotoxin substrates in different fractions of the gradient. Fig. 2(b), lane 6, shows that only fraction VI, corresponding to a density of $1 \cdot 19-1 \cdot 24 \mathrm{~g} \mathrm{ml}^{-1}$ contained the Rho protein. As expected, the Rho protein was also observed in pooled fraction I (Fig. 2b, lane 1) with a density corresponding to soluble proteins $\left(1.05 \mathrm{~g} \mathrm{~cm}^{-3}\right)$. Vanadate-sensitive ATPase activity was used as a marker enzyme for plasma membrane and assayed in different aliquots of the sucrose gradient. Aliquots from fraction IV with densities from $1 \cdot 14$ to $1 \cdot 16 \mathrm{~g} \mathrm{~cm}^{-3}$ showed no vanadate-sensitive ATPase activity $(1 \cdot 80 \mathrm{vs}$ $1.72 \mu \mathrm{mol} \mathrm{mg}{ }^{-1} \mathrm{~h}^{-1}$ in the absence vs the presence of vanadate). Aliquots from fraction $\mathrm{V}$ with densities from 1.162 to $1.183 \mathrm{~g} \mathrm{~cm}^{-3}$ showed a slight vanadate-sensitive

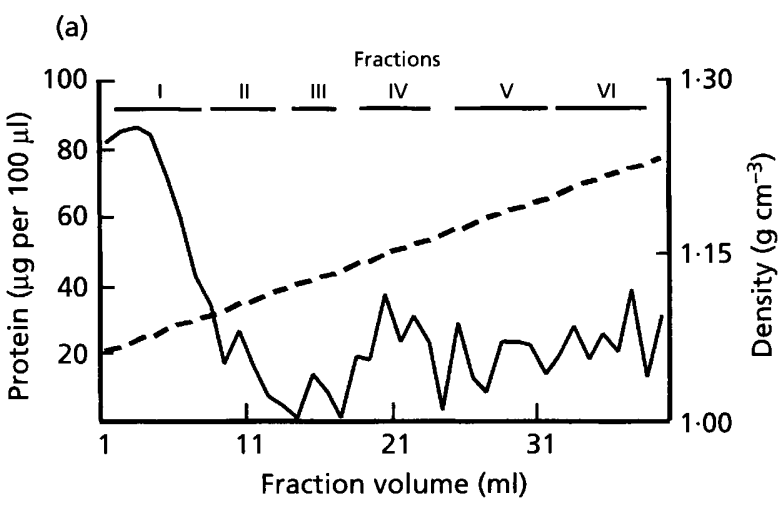

(b)

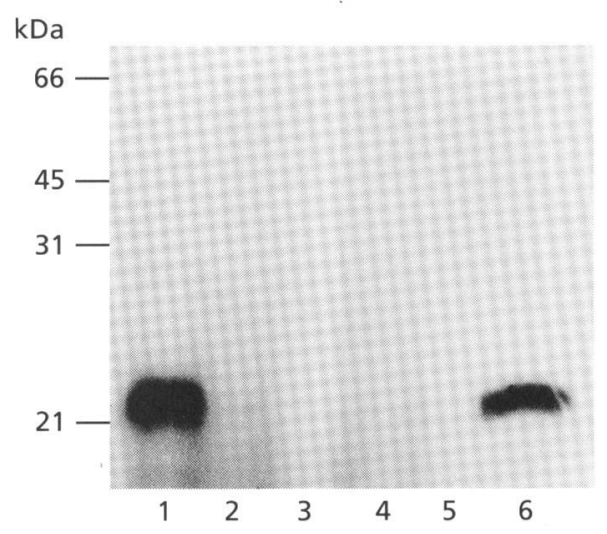

Fig. 2. ADP-ribosylation by $\mathrm{C} 3$ exotoxin in fractions of a spore homogenate separated on an isopyenic sucrose gradient. The homogenate from dormant spores was separated as follows: $3 \mathrm{ml}$ of the extract was layered on top of a linear $(20-60 \%, w / v)$ sucrose gradient which was centrifuged at $81500 \mathrm{~g}$ for $22 \mathrm{~h}$ and fractionated from the top into $1 \mathrm{ml}$ aliquots with an ISCO model 185 fractionator. Protein was determined by the Lowry method and density with an ATAGO refractometer. (a) Protein distribution in the sucrose gradient. Aliquots were pooled into six fractions with the following densities: I, 1.058-1.105; II, $1 \cdot 110-1 \cdot 124 ;$ III,1.128-1.1136; IV, 1.140-1.160; V, 1.162-1.183; VI, 1.192-1.240. (b) ADP-ribosylation in the presence of C3 exotoxin was assayed with $100 \mu \mathrm{g}$ protein from fractions I-V (lanes 1-5, respectively), and $48 \mu \mathrm{g}$ from fraction VI (lane 6). Identical results were obtained in another three experiments.

ATPase activity $\left(1.02\right.$ vs $0.72 \mu \mathrm{mol} \mathrm{mg} \mathrm{mg}^{-1} \mathrm{~h}^{-1}$ in the absence vs the presence of vanadate) and aliquots from fraction VI with densities from 1.192 to $1.24 \mathrm{~g} \mathrm{~cm}^{-3}$ showed a $66.5 \%$ inhibition of the ATPase activity by vanadate $\left(1.613\right.$ vs $0.539 \mu \mathrm{mol} \mathrm{mg}^{-1} \mathrm{~h}^{-1}$ in the absence vs the presence of vanadate). As a $22 \mathrm{kDa}$ band that was $\left[{ }^{32} \mathrm{P}\right]$ ADP-ribosylated by the $\mathrm{C} 3$ exotoxin was detected in fraction VI, we conclude that Rho is a plasma membrane protein.

\section{Identification of the Rho protein present in the spores}

Members of the Rho subfamily, specifically RhoA, RhoB and $\mathrm{RhoC}$, which are all substrates for $\mathrm{C} 3$ exotoxin, have different $\mathrm{pIs}$; for example, RhoA from mammalian cells has a pI of 5.9-6.1 (Janlink et al., 1994), RhoB a pI 
(a)

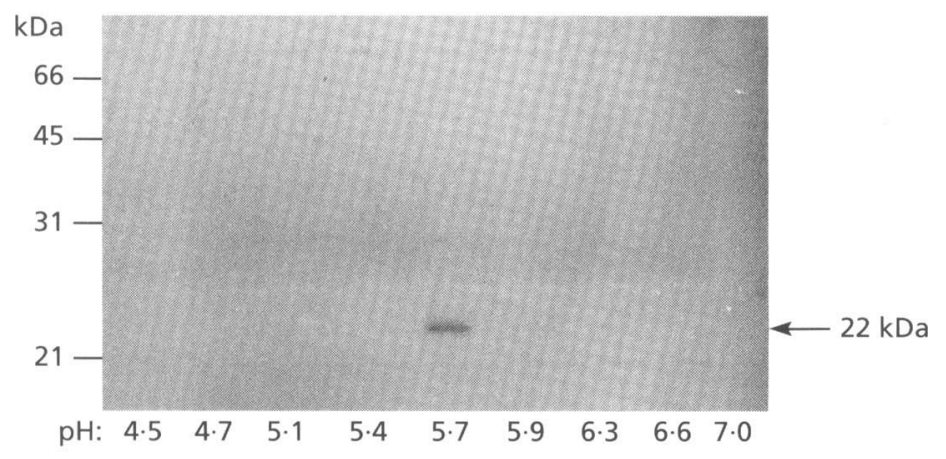

(b) $\mathrm{kDa}$

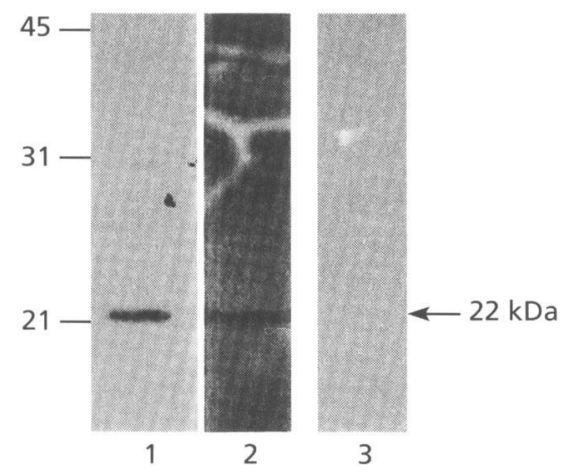

Fig. 3. Electrophoretic separation of isoelectrofocused soluble fractions. (a) Nine of the 20 fractions separated by isoelectric focusing were ADP-ribosylated in the presence of $\mathrm{C} 3$ exotoxin and subjected to SDS-PAGE. (b) Western blot analysis of RhoA of the $\mathrm{pH} 5.7$ fraction previously ADP-ribosylated (lane 1): autoradiography of the nitrocellulose membrane containing [32P]ADP-ribosylated-Rho (lane 2); incubation of the $\mathrm{pH} 5.7$ fraction in the absence of the primary and in the presence of the secondary antibody (lane 3 ). Identical results were obtained in another two experiments.

of 5.3 (Yeremian et al., 1987) and RhoC a pI of 6.8 (Nemoto et al., 1992). To investigate the $\mathrm{pI}$ of the Rho protein of $P$. blakesleeanus, the cytosol was loaded into a Rotofor Cell (Bio-Rad) for fractionation in a widerange $\mathrm{pH}$ gradient $(\mathrm{pH} 3-10)$ and separated by preparative isoelectric focusing. Each of the 20 fractions obtained after the isoelectric focusing was ADPribosylated by $\mathrm{C} 3$ exotoxin in the presence of $\left[{ }^{32} \mathrm{P}\right] \mathrm{NAD}$, and afterwards subjected to SDS-PAGE and autoradiography. One band corresponding to $22 \mathrm{kDa}$ was detected in a fraction electrofocused at pH $5 \cdot 7$ (Fig. 3a). This $\mathrm{pI}$ corresponds approximately to that reported for the RhoA protein. To corroborate the above results, immunocytochemical studies were performed using a polyclonal antibody against the RhoA protein. Fig. 3(b), lane 1 , shows that the antibody recognized a $22 \mathrm{kDa}$ protein from the same fraction of $\mathrm{pH} 5.7$ that was ADPribosylated by $\mathrm{C} 3$ exotoxin (Fig. 3b, lane 2). This band was not observed when the blot was incubated only with the secondary antibody (Fig. 3b, lane 3 ). The same result was obtained if the mixed-membrane fraction was isoelectrofocused (data not shown). These results demonstrate that $P$. blakesleeanus spores contained the RhoA protein with a $\mathrm{pI}$ of $5 \cdot 7$.

\section{Rho protein is present in different developmental stages of $P$. blakesleeanus}

The expression of the Rho protein was investigated during different stages of spore germination. Chemically activated spores were incubated in liquid complex medium and aliquots were withdrawn from the culture at different times of the differentiation process. Under the conditions used, spore swelling occurred during the first $4 \mathrm{~h}$ and germ-tube formation started at about $5.5 \mathrm{~h}$ of incubation at $24^{\circ} \mathrm{C}$. At $9 \mathrm{~h}$, the germ-tube was approximately three times the size of the swelled spore, and at $18 \mathrm{~h}$ hyphal branching had occurred (Fig. 4a). Both cytosol and mixed-membrane fractions were obtained from the cells incubated at the times indicated above and assayed for $\left[{ }^{32} \mathrm{P}\right] \mathrm{ADP}$-ribosylation with $\mathrm{C} 3$ exotoxin. The Rho protein was expressed in all stages studied, but the intensity of radiolabelling of the $\left[{ }^{32} \mathrm{P}\right]$ ADP-ribosylated protein increased in the cytosol when the tube formation occurred and afterwards the intensity of the band decreased as the hyphae branched (Fig. 4b). In the mixed-membrane fraction (Fig. 4c), the intensity of the Rho band increased after the band from the cytosolic fractions started to decrease, as expected for a protein that is synthesized first in the cytosol and afterwards processed for integration into the membrane. In addition, cytosol and mixed-membrane fractions from the above cells were separated by SDS-PAGE and then electrotransferred to nitrocellulose. Blots were subsequently incubated with the polyclonal antibody against RhoA. As shown in Fig. 4(d, e), the antibody recognized a $22 \mathrm{kDa}$ band in both cytosol (Fig. 4d) and membrane (Fig. 4e) fractions. Under the conditions of the immunodetection used, this band was not detected in all stages of growth investigated. If the blots were incubated with the primary antibody for longer periods, the $22 \mathrm{kDa}$ band was observed in all stages. This band was not detected at any stage of growth when fractions were tested solely with the secondary antibody (data not shown).

\section{Immunolocalization of Rho protein from different developmental stages of $\boldsymbol{P}$. blakesleeanus}

Since Rho was expressed differentially during spore germination, we investigated its localization during this process by immunofluorescence using a polyclonal antibody against RhoA. The presence of the RhoA protein in the spore membrane periphery and inside the cell was observed (Fig. 5a). After the spore started to swell, RhoA could be observed as patches in the cell membrane and also distributed inside the cell (Fig. 5b). When the germ-tube extruded, RhoA was observed in a zone flanking this protuberation, and this patch remained as the germ-tube continued growing (Fig. 5c, d). Fluorescence was also observed in the cytosol, 
(a)
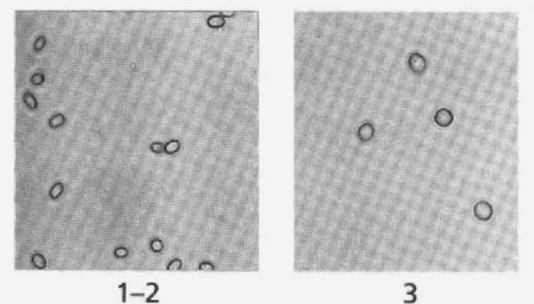

3

(b)

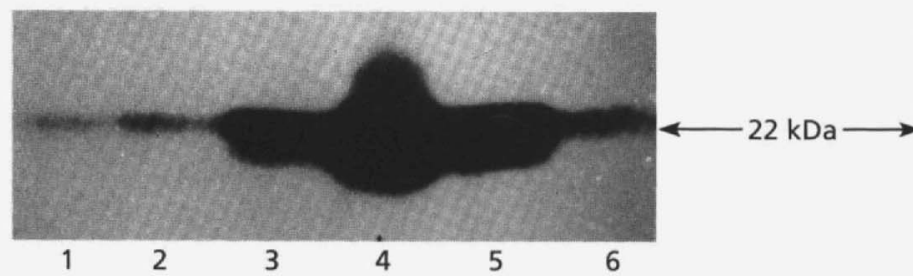

(c)

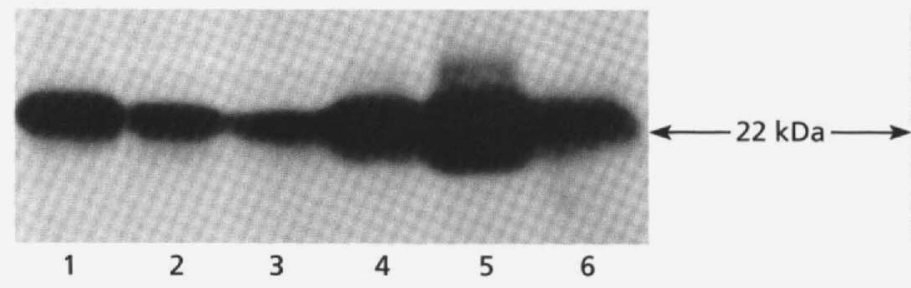

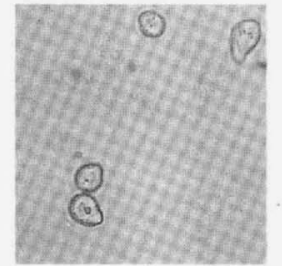

4

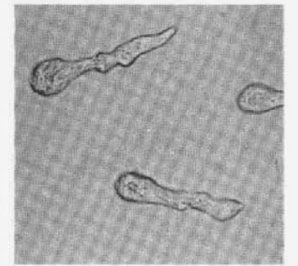

5

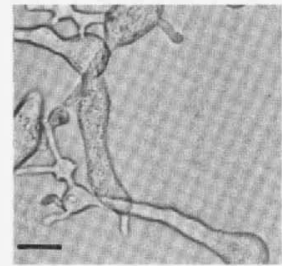

6

(d)

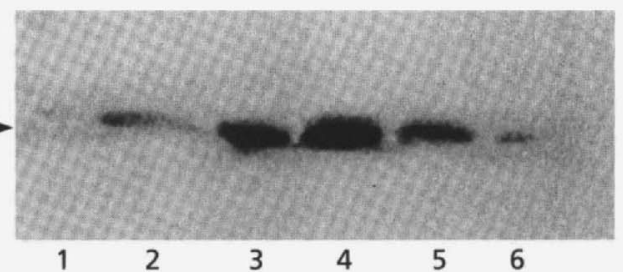

(e)

Fig. 4. Expression of Rho protein during the development of P. blakesleeanus. Cellular fractions ( $100 \mu \mathrm{g}$ protein) were separated by electrophoresis and proteins were transferred onto nitrocellulose and assayed for immunoreactivity against RhoA or were incubated under conditions for ADP-ribosylation in the presence of C3 exotoxin followed by electrophoresis and radioautography. Lanes: 1, dormant spores; 2 , spores $30 \mathrm{~min}$ after activation; 3, swelling spores; 4, cells starting to extrude a germ-tube; 5, cells with a germ-tube three times the size of the spore; 6, mycelia. (a) Morphology of the cells used for the detection of Rho (bar, $40 \mu \mathrm{m})$; (b) soluble [32P]ADP-ribosylated-Rho proteins; (c) mixed-membrane [ ${ }^{32}$ P]ADP-ribosylated-Rho proteins. (d) Western blot analysis of RhoA of soluble proteins; (e) Western blot analysis of RhoA of membrane proteins. Identical results were obtained in another four experiments.

confirming the experiments described above showing the presence of RhoA in this subcellular fraction. When cells were incubated without anti-Rho, but with the secondary antibody, these cells showed negligible fluorescence (Fig. 5e).

\section{DISCUSSION}

Rho has been found in the cytoplasm as a GDP-bound inactive form and in the plasma membrane as a GTPactive form (reviewed by Takai et al., 1995). In yeast cells, it has been demonstrated that Rho1p, a homologue of mammalian RhoA, is present in both the cytosolic and particulate fractions (McCaffrey et al., 1991; Yamochi et al., 1994). We found also that in dormant spores of P. blakesleeanus a Rho protein is present in the cytosol as well as in the plasma membrane. By isoelectric focusing and Western blot analysis with polyclonal antibodies against RhoA, it was found that the antibody recognized a $22 \mathrm{kDa}$ protein with a $\mathrm{pl}$ of 5.7 which was also a substrate for C3 exotoxin, demonstrating that $P$. blakesleeanus spores contained at least the RhoA protein.
The Rho protein was expressed in all stages of spore germination studied. Although Rho was found in both the cytoplasm and the particulate fraction, the distribution and intensity of radiolabelling of the $\left[{ }^{32} \mathrm{P}\right] \mathrm{ADP}$. ribosylated protein in the two fractions were different. Active Rho increased in the cytosolic fraction (after the extrusion of the germ-tube) prior to its increase in the membrane (at the stage when the germ-tube was three times the size of the spore). In all organisms studied to date Rho is synthesized in the cytoplasm and after its post-translational modification and activation is translocated to the membrane, where it interacts with its effectors (Takai et al., 1995). It appears that, in $P$. blakesleeanus, after Rho is synthesized in the cytoplasm this protein is modified and translocated to the cell membrane, where it may interact with a putative effector necessary for the protuberation of the germ-tube.

Yeast and fungal cells produce and maintain a large osmotic gradient across their plasma membrane, resulting in turgor pressure which is apparently used to force wall extension, allowing cell growth (Ortega et al., 1989). However, the presence of a large internal pressure presents a biophysical barrier for cell growth. Together 

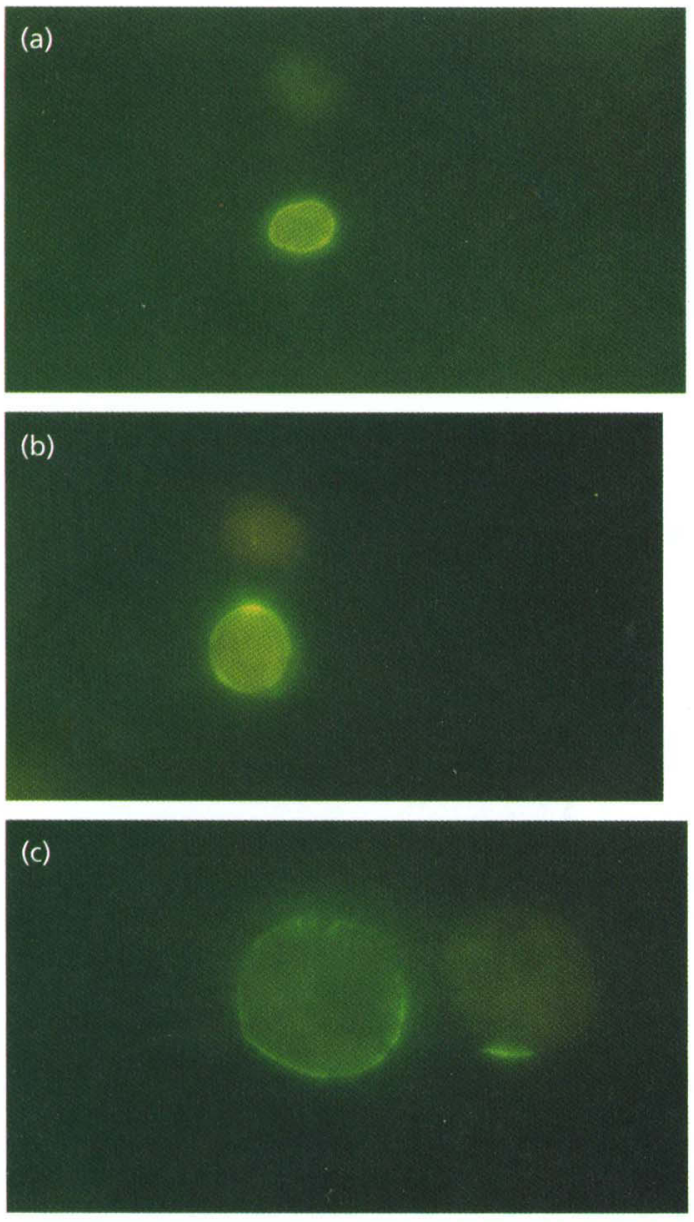

(d)

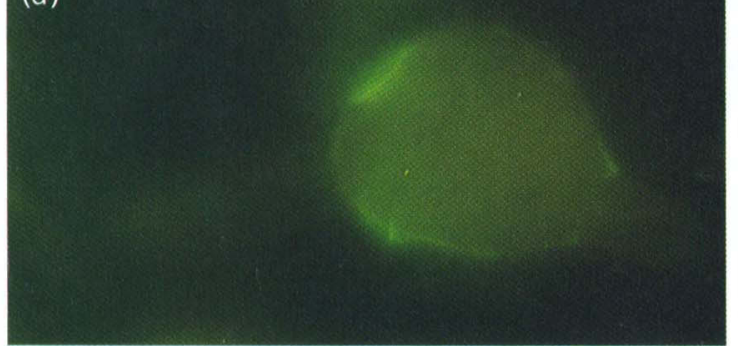

(e)

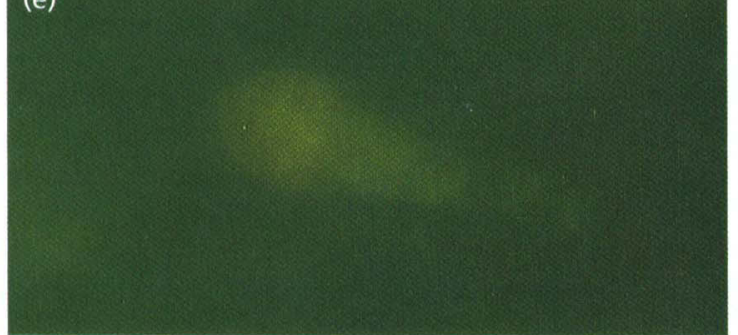

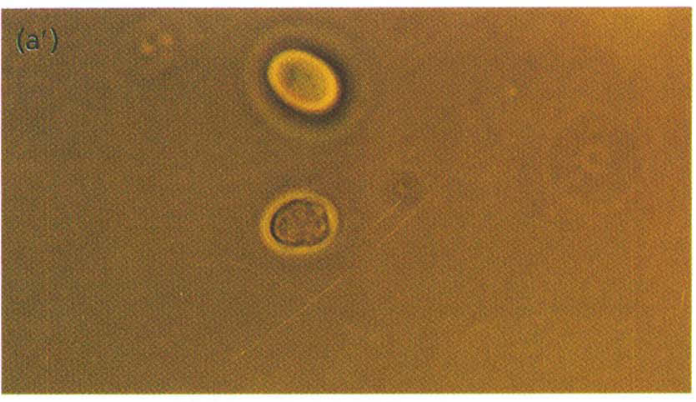
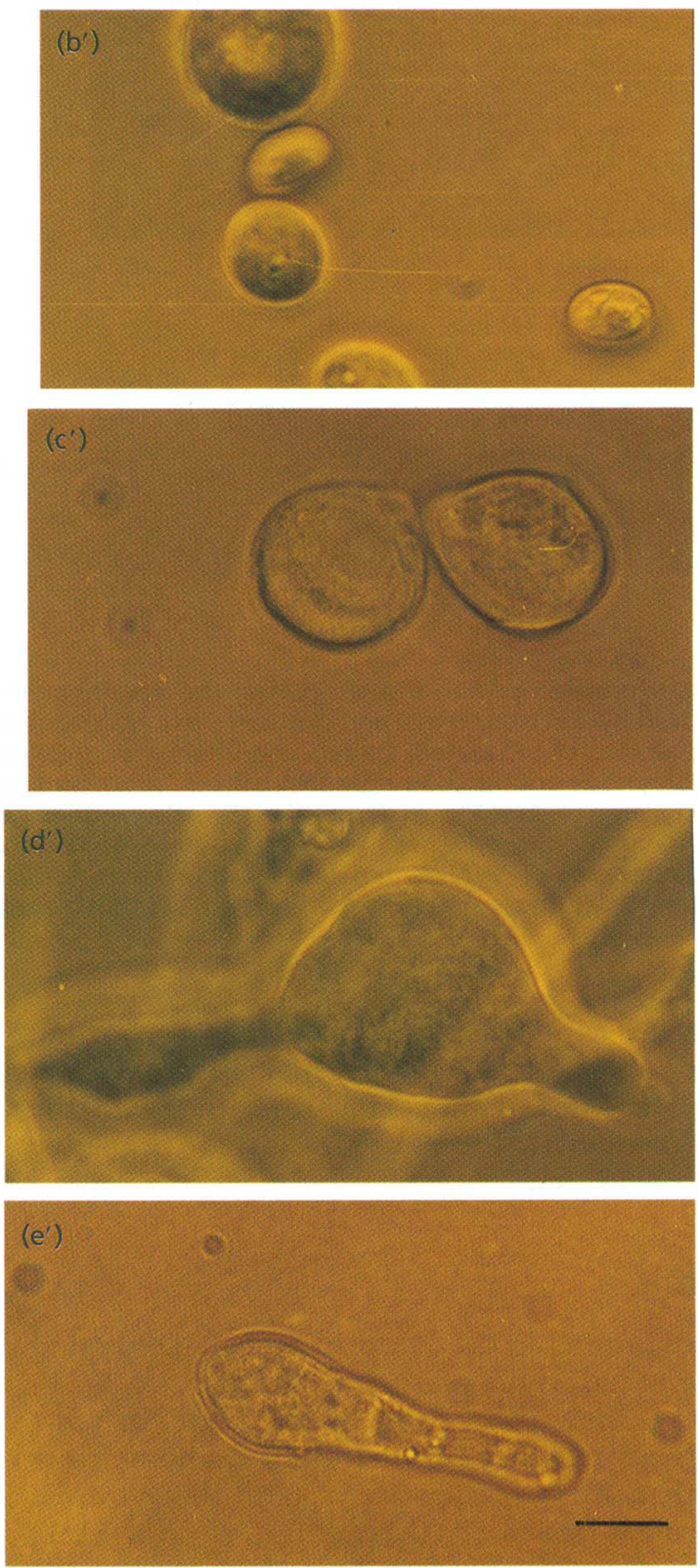

Fig. 5. Immunolocalization of RhoA protein during the development of $P$. blakesleeanus. The cells were grown at $24{ }^{\circ} \mathrm{C}$ in YPG medium. Cells were then fixed and processed for reactions against RhoA monoclonal antibodies and secondary antibody coupled with fluorescein. (a, a') Dormant spore; (b, b') swelling spore; $\left(c, c^{\prime}\right)$ cells starting to extrude a germtube; $\left(d, d^{\prime}\right)$ cells with germ-tubes three times the size of the spore; $\left(e, e^{\prime}\right)$ cell incubated with the secondary antibody and without RhoA monoclonal antibody. (a-e) Fluorescence microscopy; ( $\left.a^{\prime}-e^{\prime}\right)$ light microscopy. Bar, $10 \mu \mathrm{m}$. Identical results were obtained in another four experiments. Two hundred cells from each stage were observed $(75 \%$ of these cells presented the fluorescence shown). 
with the turgor pressure, the breaking of covalent bonds necessary for the insertion of new ones creates a predisposition to cell lysis. In Sacch. cerevisiae, Mulholland et al. (1994) reported that the cortical actin patch consists of a finger-like invagination of the plasma membrane, around which actin and associated proteins are organized. These cortical actin patches containing membrane invaginations were observed at the points of bud emergence as well as at the site of septum formation. Also, these authors suggested that the cell turgor pressure may be reduced by invaginating the cell surface wherever new wall material is inserted. Therefore, the cortical actin cytoskeleton plays a primary role in establishing and maintaining localized membrane invaginations necessary for polarized growth. The small GTP-binding protein Rholp has been co-localized at the periphery of yeast cells together with the cortical actin patches. Both are found in the site of bud emergence, the tip of the growing buds, and the mother-bud neck region of the cells prior to cytokinesis (Yamochi et al., 1994), although no direct association of Rho with the actin cytoskeleton has been reported.

During spore swelling and protrusion of the germ-tube, $P$. blakesleeanus must produce a large osmotic gradient across its plasma membrane, resulting in turgor pressure which is apparently used for wall growth. In this fungus, the extension of the cell wall during germination requires localized deposition and insertion of cell wall under osmotically prohibitive conditions. Immunofluorescence microscopy showed that RhoA is localized in a zone flanking the site of the tube protuberation as well as in the cytoplasm. This distribution of RhoA in the surface of the swelling spore and after tube protrusion suggests that RhoA together with other associated proteins could participate in reducing the turgor pressure of $P$. blakesleeanus by a similar mechanism as proposed for Sacch. cerevisiae.

Three targets of Rho1p have been reported. One target was shown to be $\mathrm{Pkc1p}$, a homologue of mammalian protein kinase C (Nonaka et al., 1995), which regulates cell wall integrity through activation of the MAP kinase cascade (Levin \& Errede, 1995). A second target is the 1,3- $\beta$-glucan synthase (Drgonová et al., 1996; Qadota et al., 1996), which is involved in cell wall synthesis. A third target of Rho1p is Bnilp, known to be implicated in cytokinesis or establishment of cell polarity in Sacch. cerevisiae (Kohno et al., 1996). Kohno et al. (1996) suggested that Bni1p probably links Rho1p with the actin cytoskeleton. P. blakesleeanus does not show 1,3$\beta$-glucan synthase activity during vegetative growth. It is therefore difficult to conceive that Rho could participate in the regulation of $1,3-\beta$-glucan synthase during spore germination. However, $\beta$-glucan is present in the cell wall of dormant spores, and the synthase might be the target of Rho during spore formation in the sporangia. Another enzyme (possibly chitin synthase) involved in the synthesis of the cell wall could be the target of Rho during the germination process.

We have previously reported the presence of protein kinase $\mathrm{C}$ activity in dormant spores of P. blakesleeanus
(Carrillo-Rayas et al., 1988). We do not know if this enzyme is involved in the maintenance of cell wall integrity of $P$. blakesleeanus, but the experiments we reported with TPA (12-O-tetradecanoyl phorbol-13acetate) suggested that protein kinase $C$ could participate in the breakdown of spore dormancy in this fungus. Therefore, this enzyme could be considered as a good candidate as a target of Rho and it may regulate spore germination via the MAP kinase cascade. Other Rho-associated proteins such as the actin cytoskeleton could participate upstream of protein kinase $C$ so that the swelling of the spore, tube protuberation and overall growth can take place.

\section{ACKNOWLEDGEMENTS}

This work was supported by the Consejo Nacional de Ciencia y Tecnología of México (Grants N305 and N3032) and the Third World Academy of Sciences (Grant BC90-111).

\section{REFERENCES}

Ames, B. N. (1966). Assay of inorganic phosphate, total phosphate and phosphatase. Methods Enzymol 8, 115-118.

Arellano, M., Durán, A. \& Pérez, P. (1996). Rho1GTPase activates the (1-3) $\beta$-D-glucan synthetase and is involved in Schizosaccharomyces pombe morphogenesis. EMBO J 15, 4584-4591.

Bartnicki-Garcia, S. \& Nickerson, W. J. (1962). Nutrition, growth, and morphogenesis of Mucor rouxii. J Bacteriol 84, 841-858.

Cabib, E., Drgonová, J. \& Drgon, T. (1998). Role of small G proteins in yeast cell polarization and wall biosynthesis. Annu Rev Biochem 67, 307-333.

Carrillo-Rayas, M. T., García-Soto, J. \& Martínez-Cadena, G. (1988). 12-O-tetradecanoyl-phorbol-13-acetate interferes with germination of Phycomyces blakesleeanus sporangiospores. FEBS Lett 238, 441-444.

Cid, V. J., Durán, A., del Rey, F., Snyder, M. P., Nombela, C. \& Sánchez, M. (1995). Molecular basis of cell integrity and morphogenesis in Saccharomyces cerevisiae. Microbiol Rev 59, 345-386.

Deveze-Alvarez, M., García-Soto, J. \& Martínez-Cadena, G. (1996). Evidence for an arginine-specific mono(ADP-ribosyl)transferase in dormant spores of Phycomyces blakesleeanus. Microbiology 142, 2907-2912.

Drgonová, J., Drgon, T., Tanaka, K., Kollár, R., Chen, G., Ford, R., Chan, C. S. M., Takai, Y. \& Cabib, E. (1996). Rho1p, a yeast protein at interface between cell polarization and morphogenesis. Science 272, 277-279.

Janlink, K., Van Croven, E. J., Hengeveld, T., Morii, N., Narumiya, S. \& Moolenaar, W. H. (1994). Inhibition of lysophosphatidate and thrombin-induced neurite retraction and neuronal cell rounding by ADP-ribosylation of the small GTP-binding protein Rho. J Cell Biol 126, 801-810.

Kohno, H., Tanaka, K., Mino, A. \& 9 other authors (1996). Bnp1 implicated in cytoskeletal control is a putative target of Rhp1p small GTP binding protein in Saccharomyces cerevisiae. EMBO J 15, 6060-6068.

Laemmli, U. K. (1970). Cleavage of structural proteins during the assembly of the head of bacteriophage T4. Nature 227, 680-685.

Levin, D. E. \& Errede, B. (1995). The proliferation of MAP kinase signaling in yeast. Curr Biol 7, 197-202. 
McCaffrey, M., Johnson, J. S., Goud, B., Myers, A. M., Rossier, J., Popoff, M. R., Madaule, P. \& Boquet, P. (1991). The small GTPbinding protein Rho1p is localized on the Golgi apparatus and post-Golgi vesicles in Saccharomyces cerevisiae. J Cell Biol 115, 309-319.

Machensky, L. \& Hall, A. (1996). Rho: a connection between membrane receptor signalling and the cytoskeleton. Trends Biol Sci 21, 304-310.

Martínez-Cadena, G., Novoa-Martínez, G., González-Hernández, A. \& García-Soto, J. (1995). The GTP-binding protein $G \alpha_{\mathrm{s}}$ is present in dormant spores and expressed differentially during spore germination of the fungus Phycomyces blakesleeanus. Microbiology 141, 3149-3154.

Mulholland, J., Preuss, D., Moon, A., Wong, A., Drubin, D. \& Bolstein, D. (1994). Ultrastructure of the yeast actin cytoskeleton and its association with the plasma membrane. J Cell Biol 125, 381-391.

Nemoto, Y., Namba, T., Teru-uchi, T., Morii, N. \& Narumiya, S. (1992). A Rho gene product in human platelets. Identification of the platelet substrate for botulinum C3 ADP-ribosyltransferase as RhoA protein. J Biol Chem 268, 20916-20920.

Nobes, C. \& Hall, A. (1994). Regulation and function of the Rho subfamily of small GTPases. Curr Opin Genet Dev 4, 77-81.

Nonaka, H., Tanaka, K., Hirano, H., Fujiwara, T., Kohno, H., Umikawa, M., Mino, A. \& Takai, Y. (1995). A downstream target of RHO1 small GTP-binding protein is PKC1, a homologue of protein kinase $\mathrm{C}$, which leads to activation of the MAP kinase cascade in Saccharomyces cerevisiae. EMBO J 15, 5931-5938.

Ortega, J. K. E., Zehr, E. G. \& Keanini, G. (1989). In vivo creep and stress relaxation experiments to determine the wall extensibility and yield threshold for sporangiophores of Phycomyces. Biophys J 56, 465-475.
Qadota, H., Python, C. P., Inoue, S. B., Arisawa, M., Anraku, Y., Zheng, Y., Watanabe, T., Levin, D. E. \& Onya, Y. (1996). Identification of yeast Rho1p-GTPase as a regulatory subunit of 1-3 $\beta$-glucan synthase. Science 272, 279-281.

Ridley, A. J. \& Hall, A. (1994). Signal transduction pathways regulating Rho-mediated stress fibre formation requirement for a tyrosine kinase. $E M B O J 13,2600-2610$.

Sekine, A., Fujiwara, M. \& Narumiya, S. (1989). Asparagine residue in rho gene products is a modification site for botulinum ADP-ribosyltransferase. J Biol Chem 264, 8602-8605.

Takai, Y., Sasaki, T., Tanaka, K. \& Nakanishi, H. (1995). Rho as a regulator of cytoskeleton. Trends Biol Sci 20, 227-231.

Towbin, H., Staehelin, T. \& Gordon, J. (1979). Electrophoretic transfer of proteins from polyacrylamide gels to nitrocellulose sheets : procedure and some applications. Proc Natl Acad Sci USA 76, 4350-4354.

Van Laere, A. J., Van Assche, J. A. \& Furch, B. (1987). The sporangiospore: dormancy and germination. In Phycomyces, pp. 247-279. Edited by E. Cerdá-Olmedo \& E. D. Lipson. Cold Spring Harbor, NY: Cold Spring Harbor Laboratory.

Yamochi, W., Tanaka, K., Nonaka, H., Maeda, A., Musha, T. \& Takai, Y. (1994). Growth site localization of Rho1p small GTPbinding protein and its involvement in bud formation in Saccharomyces cerevisiae. J Cell Biol 125, 1077-1093.

Yeremian, P., Chardin, P., Madaule, P. \& Tavitan, A. (1987). Nucleotide sequence of human tho cDNA clone 12. Nucleic Acids Res 15, 1869.

Received 4 December 1998; accepted 20 January 1999. 